Article

\title{
Economic and Technical Aspects of Flexible Storage Photovoltaic Systems in Europe
}

\author{
Henrik Zsiborács ${ }^{1}$, Nóra Hegedúsné Baranyai ${ }^{1, *}$, András Vincze ${ }^{2}$, István Háber ${ }^{3}$ \\ and Gábor Pintér 1 \\ 1 Department of Economic Methodology, University of Pannonia, Georgikon Faculty, \\ 8360 Keszthely, Hungary; ifj.zsiboracs.henrik@gmail.com (H.Z.); pg@georgikon.hu (G.P.) \\ 2 Department of Foreign Languages, University of Pannonia, Georgikon Faculty, \\ 8360 Keszthely, Hungary; vinander@t-online.hu \\ 3 Department of Mechanical Engineering, University of Pécs, Faculty of Engineering and \\ Information Technology, 7624 Pécs, Hungary; ihaber@gmail.com \\ * Correspondence: baranyai@georgikon.hu; Tel.: +36-30-373-8550
}

Received: 18 May 2018; Accepted: 1 June 2018; Published: 4 June 2018

\begin{abstract}
Solar energy has an increasing role in the global energy mix. The need for flexible storage photovoltaic systems and energy storage in electricity networks is becoming increasingly important as more generating capacity uses solar and wind energy. This paper is a study on the economic questions related to flexible storage photovoltaic systems of household size in 2018. The aim is to clarify whether it is possible in the European Union to achieve a payback of the costs of flexible storage photovoltaic system investments for residential customers considering the technology-specific storage aspects prevalent in 2018. We studied seven different flexible storage photovoltaic investments with different battery technologies in Germany, France, Italy, and Spain because, in Europe, these countries have a prominent role with regard to the spread of photovoltaic technology. These investment alternatives are studied with the help of economic indicators for the different cases of the selected countries. At the end of our paper we come to the conclusion that an investment of a flexible storage photovoltaic (PV) system with Olivine-type-LiFePO 4 , Lithium-Ion, Vented lead-acid battery (OPzS), Sealed lead-acid battery (OPzV), and Aqueous Hybrid Ion (AHI) batteries can have a positive net present value due to the high electricity prices in Germany and in Spain. The most cost-effective technology was the Olivine-type- $\mathrm{LiFePO}_{4}$ and the Lithium-Ion at the time of the study. We suggest the provision of governmental support and uniform European modifications to the regulatory framework, especially concerning grid fees and tariffs, which would be necessary in the beginning to help to introduce these flexible storage PV systems to the market.
\end{abstract}

Keywords: solar energy; photovoltaic system; flexible storage system; battery efficiency

\section{Introduction}

\subsection{Change in the Spread of Photovoltaic (PV) Technology in Europe}

The global energy demand is increasing day by day, and the shift to a sustainable, low-carbon economy will require innovation and the deployment of a range of low-carbon technologies for providing energy and other services [1,2]. Today, the greenhouse effect and global warming are the most important hazards for the Earth's future. One possible optimal solution to stop their adverse influences on human life is using renewable energy sources, since they are green, clean, environment-friendly, and sustainable $[3,4]$. Global warming has pushed the whole energy sector towards low-carbon energy resources, and photovoltaic (PV) sources have a key role in this transition [5-7]. 
PV technology is an essential pillar for transforming our energy systems into one based on renewable and sustainable energy sources [8]. The share of renewable electricity production represented $24.5 \%$ of all electricity produced globally in 2016, of which PV technology accounted for $1.5 \%$. PV systems have largely penetrated the global energy market, especially in Europe. In 2016, the global solar PV capacity was $303 \mathrm{GW}$, with the largest proportions being the European Union's 106 GW, China's 77.4 GW, Japan's 42.8 GW, and the USA's 40.9 GW [9-11]. Today, in many emerging markets, PV technology is considered a cost-competitive source for increasing electricity production and for providing energy access. Nonetheless, markets in most locations continue to be driven largely by regulations or government incentives [11-13]. The European Union became the first region to pass the 100 GW milestone in 2016 [11,14]. Germany, France, Italy, and Spain have a prominent role in the spread of PV technology in Europe. Based on reference data, by 2050, the net PV production capacity in the EU will be +197.3 GW higher than in 2015 [15] (Figure 1).
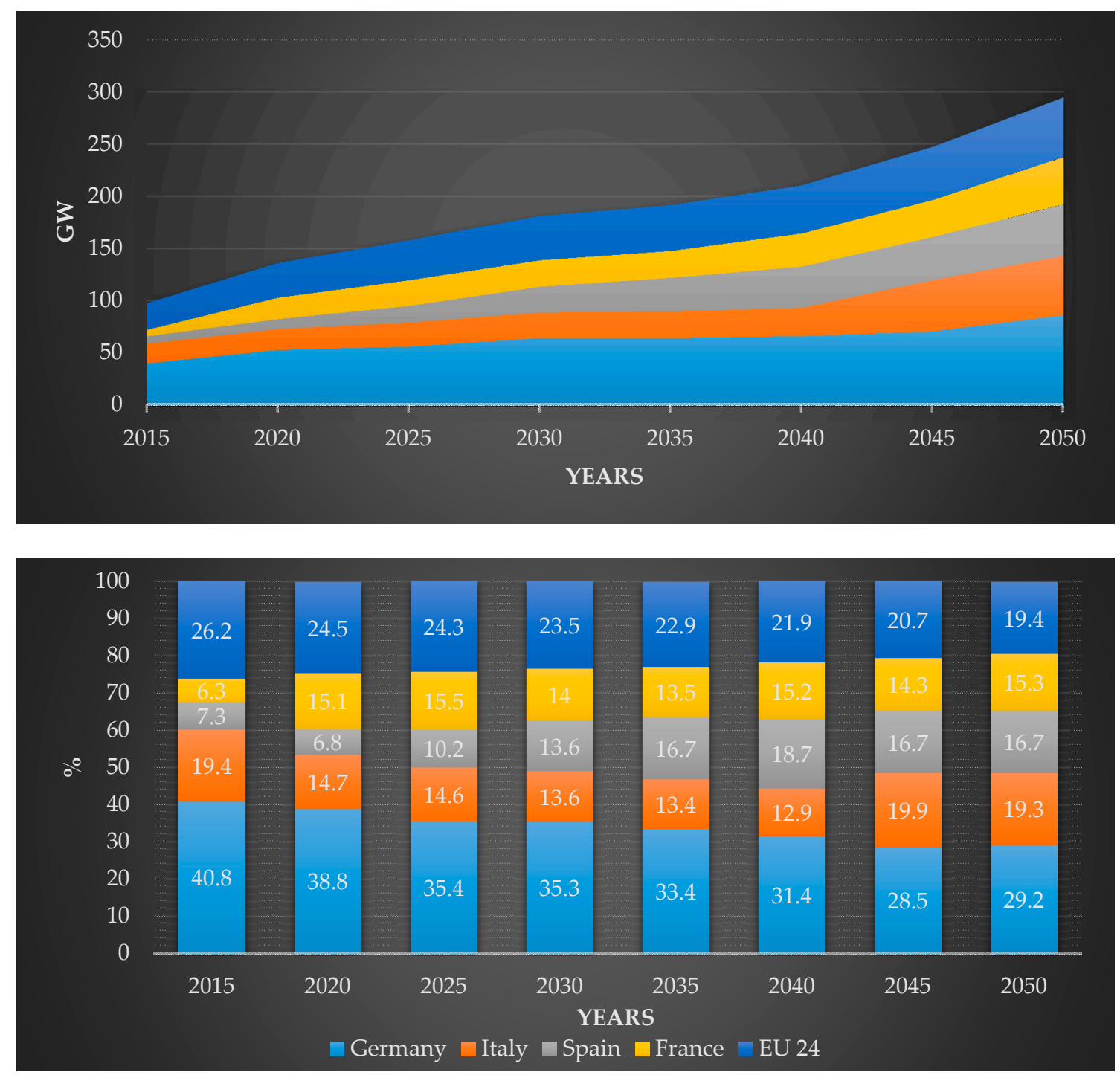

Figure 1. Net photovoltaic (PV) production capacity change based on EU Reference Scenario 2016 [15]. 


\subsection{Change in the Spread of Energy Storage}

Energy storage is one of several potentially important technologies enabling and supporting the large-scale deployment of renewable energy, particularly variable renewables such as wind and PV energy [16,17]. The most important uses of energy storage are [18].

- renewables capacity firming;

- renewables energy time shift;

- onsite renewable generation shifting;

- electric energy time shift;

- electric bill management;

- frequency regulation;

- voltage support;

- electric supply capacity.

As shown in Figure 1 the need for energy storage in electricity networks is becoming increasingly important, as more and more generating capacity uses renewable energy sources that are intrinsically intermittent, while electricity systems need to be constantly in balance. The key to addressing the variability and uncertainty of variable renewable electricity integration is the increasing of the overall flexibility in the power system. Energy storage can provide a variety of flexibility services, including provision of operating reserves and shifting energy over time to better match generation and load [16,17,19-23]. Storage can provide both downward and upward flexibility, storing energy either when there is generation surplus or lower demand and discharging in the opposite case [24-26]. With respect to applications for the daily balancing of demand and supply in the electricity system, large-scale storage options such as pumped hydro storage, molten salt thermal storage, flywheel, compressed air storage, or battery systems are of main interest [27-31].

The global stationary and grid-connected energy storage capacity in 2016 totaled an estimated $156.4 \mathrm{GW}$, with pumped storage hydropower accounting for the vast majority $(150 \mathrm{GW})$. The rest of this sector focuses on energy storage other than pumped storage. Around $0.8 \mathrm{GW}$ of new advanced energy storage capacity became operational in 2016, bringing the year-end capacity total to an estimated 6.4 GW. Most of the growth was in electrochemical (battery) storage, which increased by $0.6 \mathrm{GW}$ for a total of 1.7 GW. Lithium-ion batteries comprised the majority of new capacity installed [15,32-34]. The rechargeable battery is one of the most widely used electrical energy storage technologies in daily life and industry [35]. Electrochemical (battery) storage is attractive because it is easy to deploy, already economical, compact, and provides virtually instant response both to the input from the battery and the output from the network to the battery [36].

In the future, energy storage will play an increasingly important role in enabling the effective integration of photovoltaic energy and unlocking the benefits of local generation and a resilient, green energy supply. Storage and transmission have a synergistic effect on decreasing the average $\mathrm{CO}_{2}$ emissions and the electricity price and it allows the achievement of more challenging targets for $\mathrm{CO}_{2}$ emissions at a lower cost. Grid operators all over the world must manage the variable PV energy generation more efficiently. Due to the current EU project development trends new flexible energy storage systems have mainly been concentrated in the highly developed economic regions. Without governmental support it is difficult to successfully implement energy storage system projects because despite the rapidly falling costs these investments are still expensive. This economic aspect will be improved greatly by the development of electrochemical storage systems in the future because according to forecasts the installation costs of battery storage systems will be significantly reduced by 2030 (Figure 2) [24,27,37-39]. The Bloomberg New Energy Finance study showed in the case of household size that the median flexible storage photovoltaic system payback period is more than 25 years in 2018 [40] (Figure 3). An important question is whether it is possible in the European Union to achieve a payback of the costs of flexible storage photovoltaic system investments for residential customers considering the technology-specific storage aspects prevalent in 2018. 


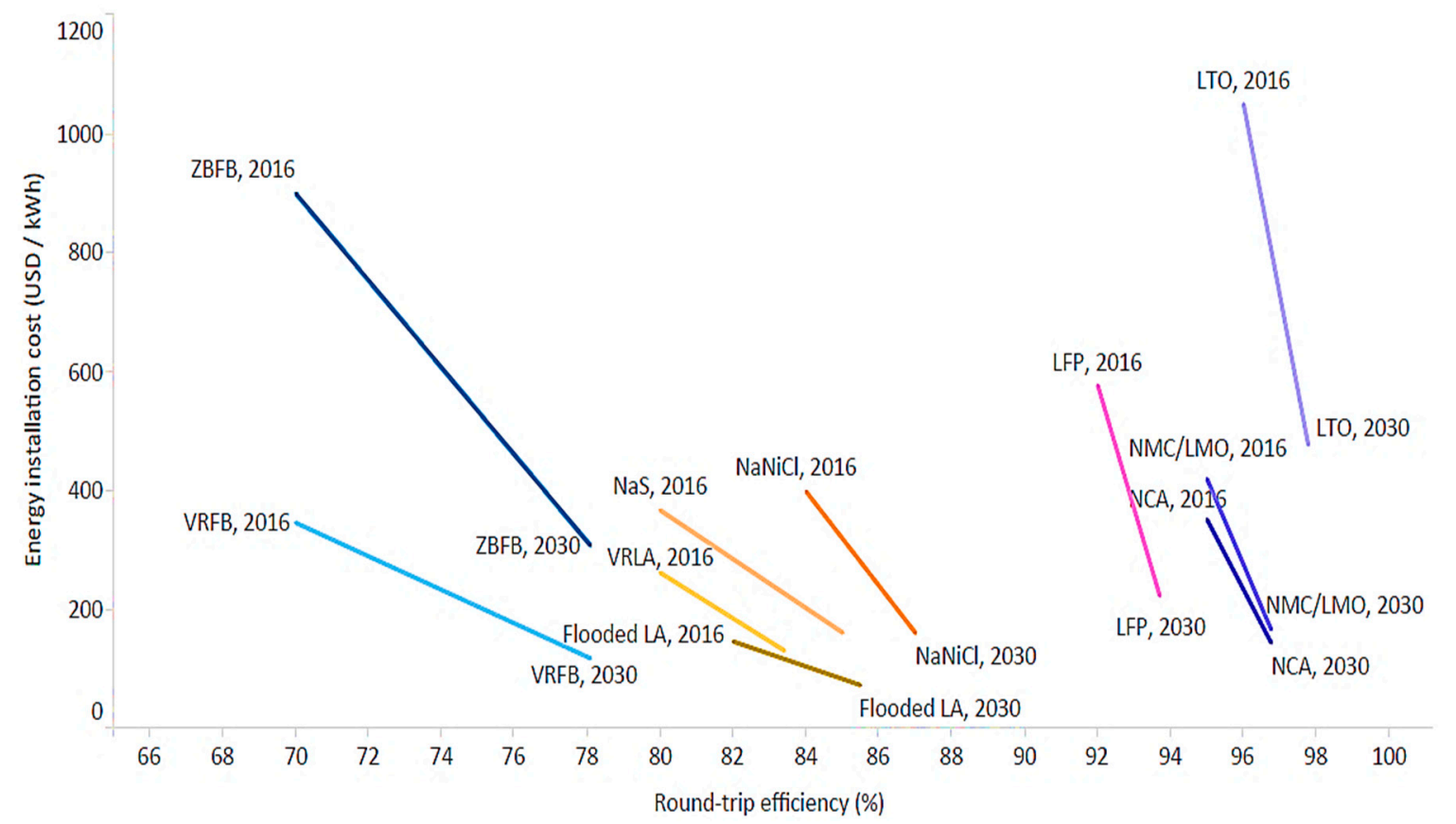

Figure 2. Energy round-trip efficiencies and installation costs of electrochemical technologies, 2016-2030 [27]. Abbreviations: LA = lead-acid; VRLA = valve-regulated lead-acid; NaS = sodium sulphur; $\mathrm{NaNiCl}$ = sodium nickel chloride; $\mathrm{VRFB}$ = vanadium redox flow battery; $\mathrm{ZBFB}=$ zinc bromine flow battery; $\mathrm{NCA}$ = nickel cobalt aluminium; $\mathrm{NMC} / \mathrm{LMO}=$ nickel manganese cobalt oxide/lithium manganese oxide; LFP = lithium iron phosphate; LTO = lithium titanate.

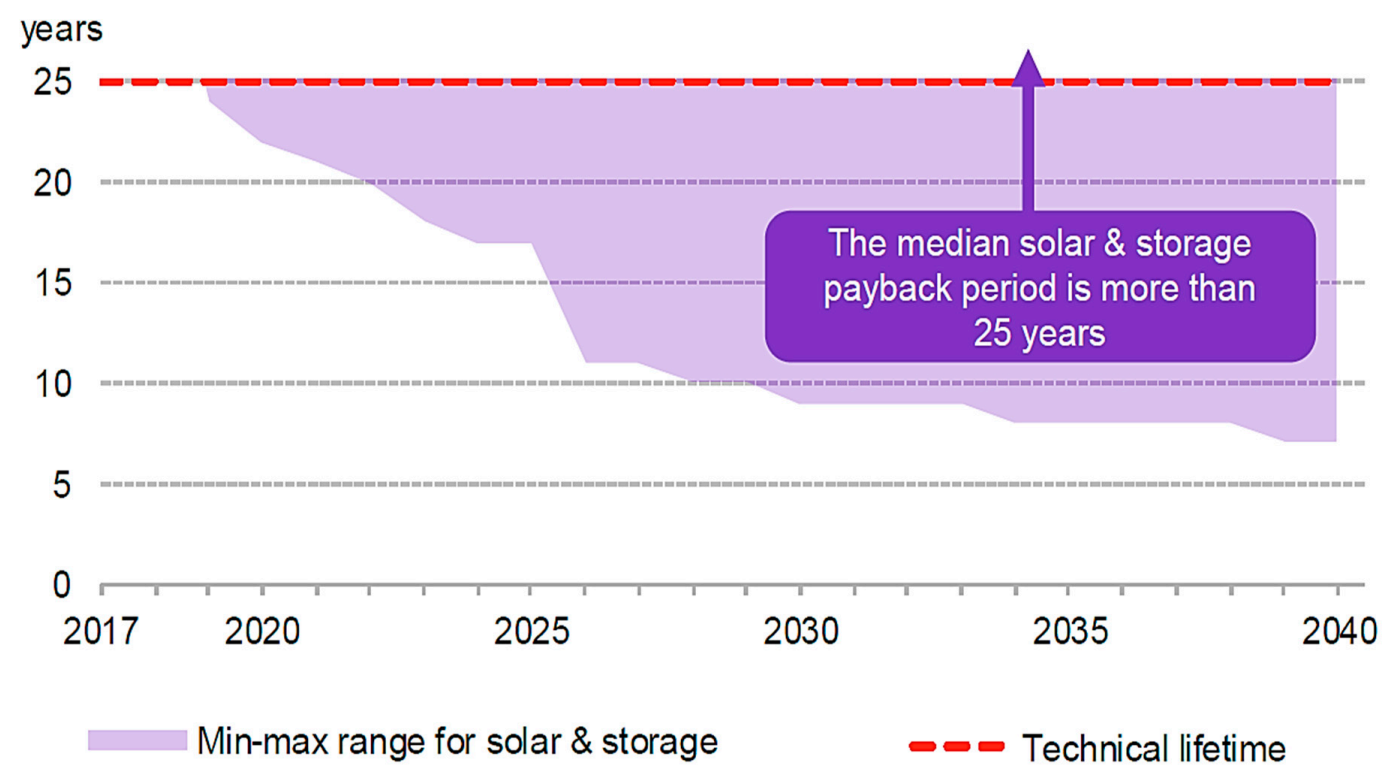

Figure 3. Payback period for residential small-scale PV systems with storage in Europe [40].

\section{Methods and Details of the Technical and Economic Assessment}

Our work deals with the economic questions of grid-tied PV-electrochemical (battery) storage or flexible storage photovoltaic systems of household size in 2018. These solutions can be described as off-grid-grid-tied systems with extra battery storage or utility backup power, which increases the security of the energy supply (Figure 4). 


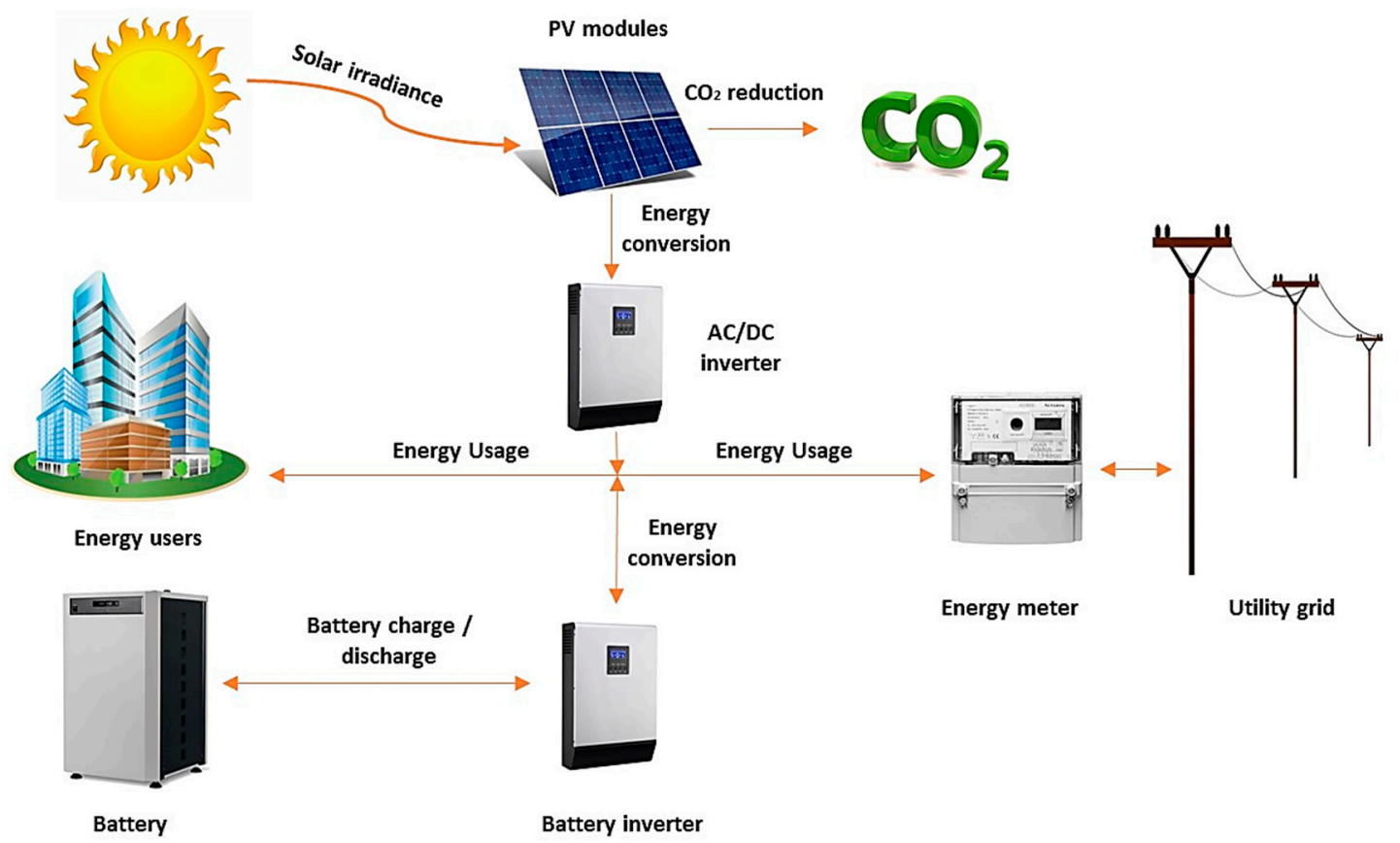

Figure 4. Example of single-phase on-grid system based on SUNNY ISLAND data sheet and technology brochures [41].

We studied seven different flexible storage photovoltaic investments with different battery technologies in Germany, France, Italy and Spain because in Europe these countries have a prominent role with regard to the spread of photovoltaic technology [15].

\subsection{Meteorological Background}

The price of electricity delivery and the intensity of solar radiation vary significantly from country to country resulting in significant differences in assessing the cost efficiency of creating such systems. Table 1 presents the global irradiation conditions of various countries together with the electric energy that could be produced by a $1 \mathrm{~kW}$ PV system. Environmental factors, such as changes in the temperature and the geographic specific irradiation, affect the output power of a PV system [42]. For PV energy simulations, we used the Photovoltaic Geographical Information System (PVGIS). Data from the PVGIS included real climatic data series of several decades [43]. These data were used for economic calculations as well. Cities where the global horizontal irradiation (GHI) is higher than the average value and real systems work with online data services were selected for calculations (Table 1). These databases are used to combine PV with battery system sizing in combination too [44].

Table 1. Data of global horizontal irradiation (GHI) and electric energy production in the studied countries [43,45-49].

\begin{tabular}{|c|c|c|c|c|c|}
\hline Subject & World & Germany & Italy & Spain & France \\
\hline $\begin{array}{l}\text { Average min. and max. global horizontal irradiation } \\
\text { by country }\left(\mathrm{kWh} / \mathrm{m}^{2} / \text { year }\right)\end{array}$ & $800-2800$ & $950-1250$ & 950-1850 & 1150-1950 & 1050-1700 \\
\hline $\begin{array}{l}\text { Average min. and max. electric energy production of } \\
1 \mathrm{~kW} \mathrm{PV} \mathrm{system} \mathrm{by} \mathrm{country} \mathrm{(kWh/year)}\end{array}$ & & 1080-1150 & $1100-1800$ & 1170-1790 & $1110-1630$ \\
\hline Selected city & & Munich & Naples & Madrid & Toulouse \\
\hline $\begin{array}{l}\text { Average global horizontal irradiation by city } \\
\qquad\left(\mathrm{kWh} / \mathrm{m}^{2} / \text { year }\right)\end{array}$ & & 1200 & 1600 & 1800 & 1350 \\
\hline $\begin{array}{l}\text { Real average electric energy production of } 1 \mathrm{~kW} \mathrm{PV} \\
\text { system by city (kWh/year) }\end{array}$ & & 1122 & 1407 & 1482 & 1374 \\
\hline
\end{tabular}




\subsection{Technological Background}

It is possible for residential customers in the analyzed countries to input extra energy produced by PV systems into the national electricity network in the framework of household size [50].

The decrease of annual performance in the case of monocrystalline modules ( $\mathrm{m}$-Si modules) and polycrystalline modules ( $\mathrm{p}$-Si modules) was determined to be around $0.5 \%$, which is a generally accepted value [51].

Battery technologies are developing rapidly with energy density and cheaper materials in the main focus. In order to achieve higher density, new material structures can be utilized: graphene as a carbon allotrope [52], Toyota's lithium sulfide solid-state battery [53], gold nanowiring of batteries [54], $3 \mathrm{D}$ reconstructed anodes and cathodes in lithium batteries [55], or just new architecture of Li-ion batteries [56]. The last three types are connected to 3D printing, which shows that combining materials science with new technologies can also lead to new inventions. However, these are not marketed yet, so older solutions have to be used in combination with PV systems.

The following PV battery technologies were analyzed because they are easily and quickly accessible to the public [57]:

- Absorbent Glass Mat, Absorbent Glass Mat (AGM);

- Aqueous Hybrid Ion, AHI-salt water;

- Lithium-Ion, Li-ion (lithium manganese oxide, nickel-cobalt manganese or lithium nickel manganese cobalt oxide;

- $\quad$ Lithium-Iron-Phosphate, $\mathrm{LiFePO}_{4}$;

- Olivine-type-Lithium-Iron-Phosphate, Olivine-type-LiFePO

- Vented lead-acid battery, OPzS;

- Sealed lead-acid battery, OPzV.

The temperature of the batteries was kept ideal with a 10-12-h discharge. An interval of 30 years was studied, mainly due to the longest Olivine-type- $\mathrm{LiFePO}_{4}$ battery life (Table 2). Four-person households with the average energy consumptions of the respective countries were examined. During the studied time period maintenance work needs to be carried out at the end of the battery life and also the inverters need to be replaced every 10 years. For the calculations a crystalline, $5 \mathrm{~kW}$ nominal power household PV system was used together with an SMA Sunny Boy $5000 \mathrm{tl}$ PV inverter (SMA Solar Technology AG, Niestetal, Germany) and an SMA Sunny Island 4.4 M battery inverter (SMA Solar Technology AG, Niestetal, Germany) because of their reliability. For the calculations a battery with an $8 \mathrm{kWh}$ nominal energy capacity was chosen, which is considered above-average in size (Figure 5) [58]. It was assumed that new batteries will have to be purchased after the average battery lifespan based on the global horizontal irradiation (GHI) and electric energy production in the studied countries (Tables 1 and 2) an interval of 30 years based on the seasonal features. The calculations included several system losses (Table 2), $180^{\circ}$ orientation (azimuth), and a tilt angle of $35^{\circ}$. Table 3 shows the technical features considered.

The following equipment, materials, and services are required for a flexible storage PV system:

- PV modules;

- PV-inverter;

- battery-inverter;

- battery;

- battery remote control;

- $\quad$ energy manager system;

- frame on roof; 
- cable with outlets;

- $\quad$ additional electric outfit;

- costs of design;

- installation and transportation.

In this study, the same flexible storage PV system costs were used for calculations for all the countries (Germany, Italy, Spain, and France). However, different technologies have different investment costs. The difference between the minimum and the maximum investment cost can even reach 8000 Euros. The $\mathrm{LiFePO}_{4}$ battery technology has the highest investment cost and the AGM battery technology has the lowest. The investment costs for a complete flexible storage PV system are shown in Figure 5.

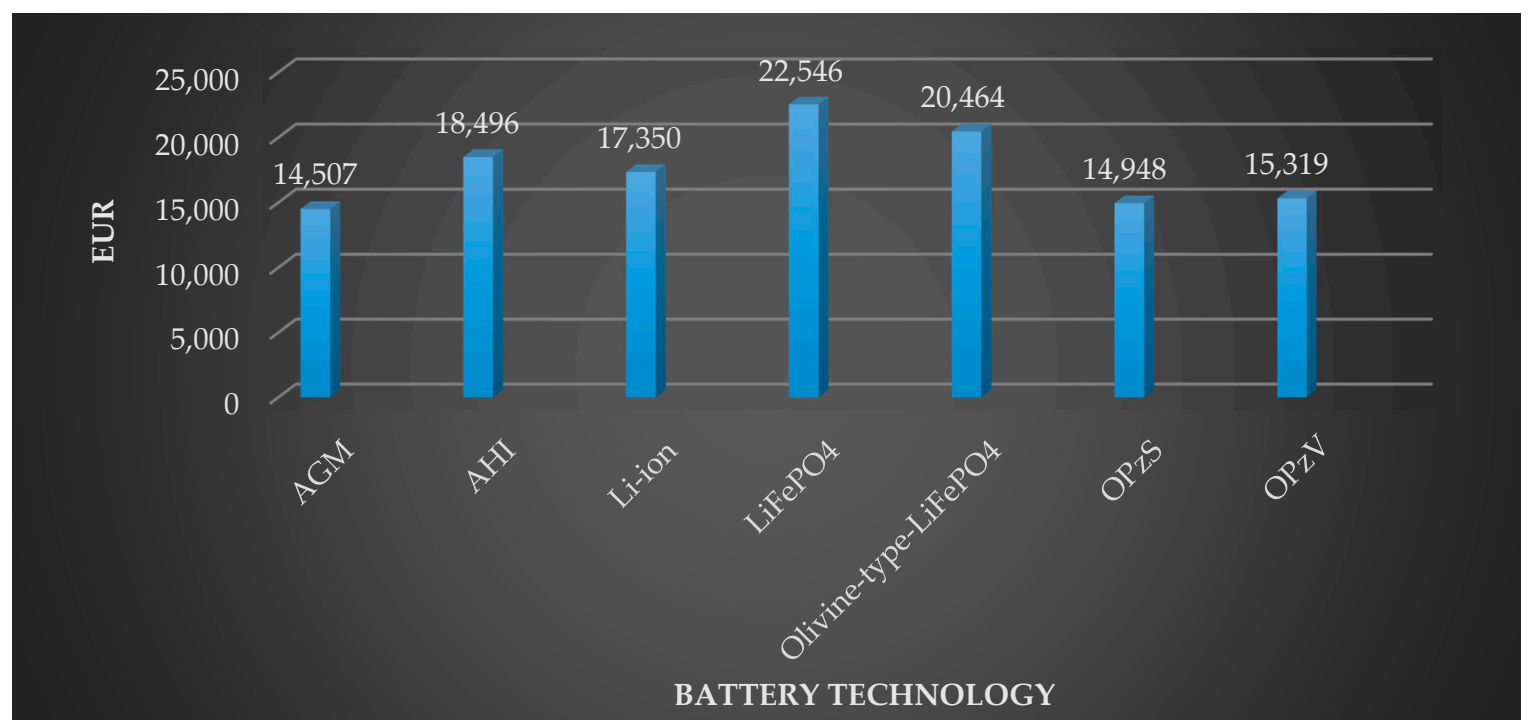

Figure 5. Total average investment costs for a complete flexible storage PV system by battery technology [59-61].

Table 2. Efficiency by flexible storage solution and the technical and economic features of selected batteries [27,41,62-83].

\begin{tabular}{ccccccccc}
\hline Energy on PV module (\%) & \multicolumn{7}{c}{100} \\
\hline System loss, PV inverter, grid (\%) & \multicolumn{7}{c}{90.3} \\
\hline Battery technology & AGM & AHI & Li-ion & LiFePO $_{4}$ & Olivine-type-LiFePO & OPzS & OPzV \\
\hline Average PV battery efficiency (\%) & 89 & 90 & 92 & 95 & 98 & 92 & 92 \\
\hline $\begin{array}{c}\text { System loss, PV inverter, battery inverter, } \\
\text { battery, battery inverter, grid (\%) }\end{array}$ & 73.0 & 73.8 & 75.5 & 77.9 & 80.4 & 75.5 & 75.5 \\
\hline $\begin{array}{c}\text { Depth of discharge (DOD) (\%) } \\
\text { Average cycle stability based on depth of } \\
\text { discharge (DOD) (cycles) }\end{array}$ & 70 & $100 *$ & 80 & 80 & $100 *$ & 80 & 80 \\
\hline $\begin{array}{c}\text { Average energy storage capacity change } \\
\text { after 1 charge/discharge (\%) }\end{array}$ & 0.057 & 0.01 & 0.005 & 0.0033 & 0.0029 & 0.025 & 0.0308 \\
\hline $\begin{array}{c}\text { Cost of 1 kWh nominal battery capacity } \\
\text { in 2018 (EUR/kWh) }\end{array}$ & 213 & 713 & 574 & 1223 & 9603 & 275 & 322 \\
\hline
\end{tabular}

* Charge/discharge cycle does not depend on DOD. 
The energy management was analyzed as follows:

- We determined the monthly total energy data.

- For our calculations we assumed 50\% direct PV energy (as daytime use) usage based on the average electricity consumption of households (Table 3) with smart regulation.

- For the rest of the energy consumption, the battery energy usage (as evening use) was calculated considering the Depth of discharge (DOD) and the system losses.

- We assumed that if the flexible storage annual energy production of a PV system is more than the average electricity consumption, and the extra PV energy will result in extra revenue by the delivery price.

- On the other hand, if the PV or battery energy production level is too low, direct energy consumption from the grid is taken into account.

We illustrated the main logic with the energy balance data of an actual flexible storage PV system in Figure 6.

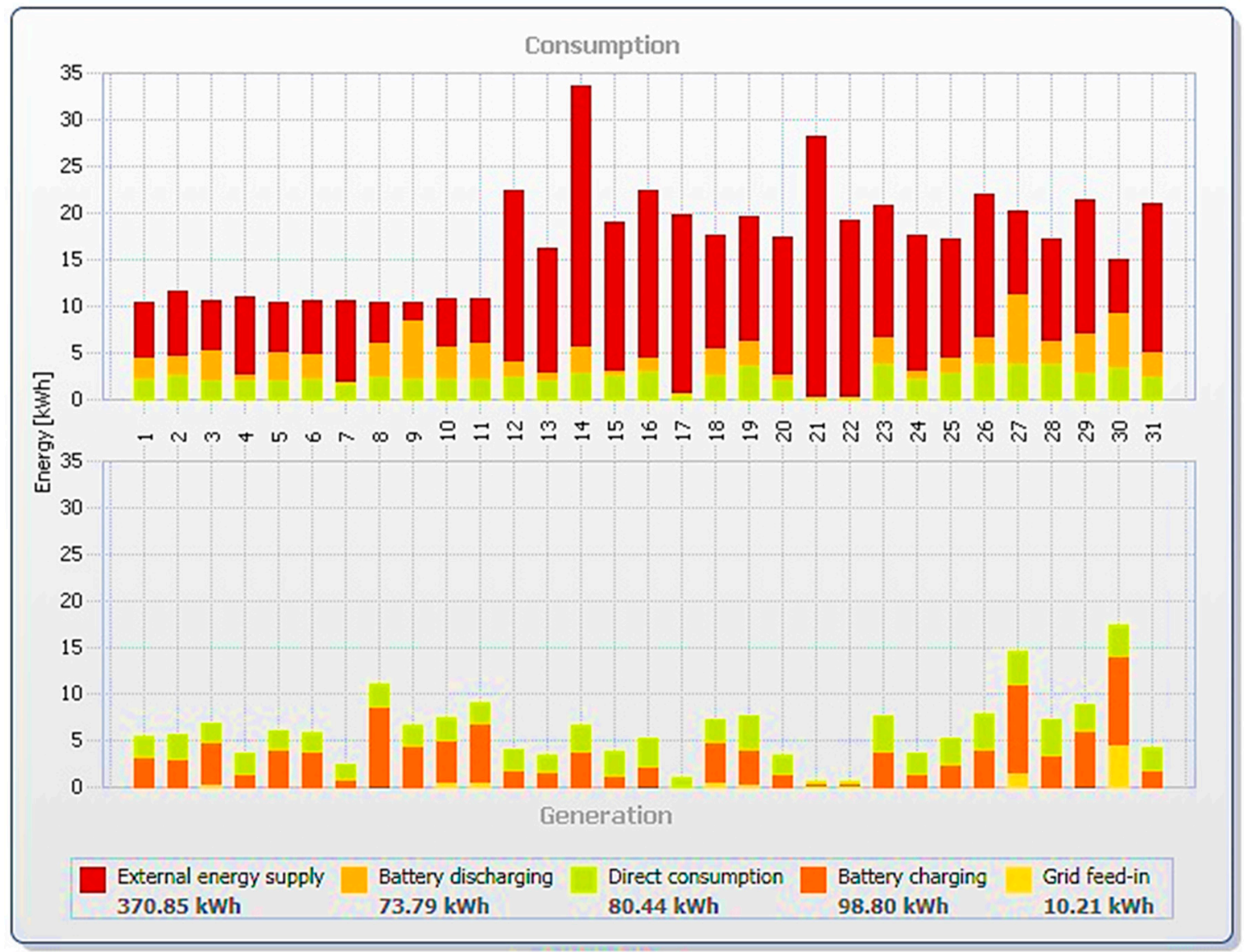

January 2018

Figure 6. Cont. 


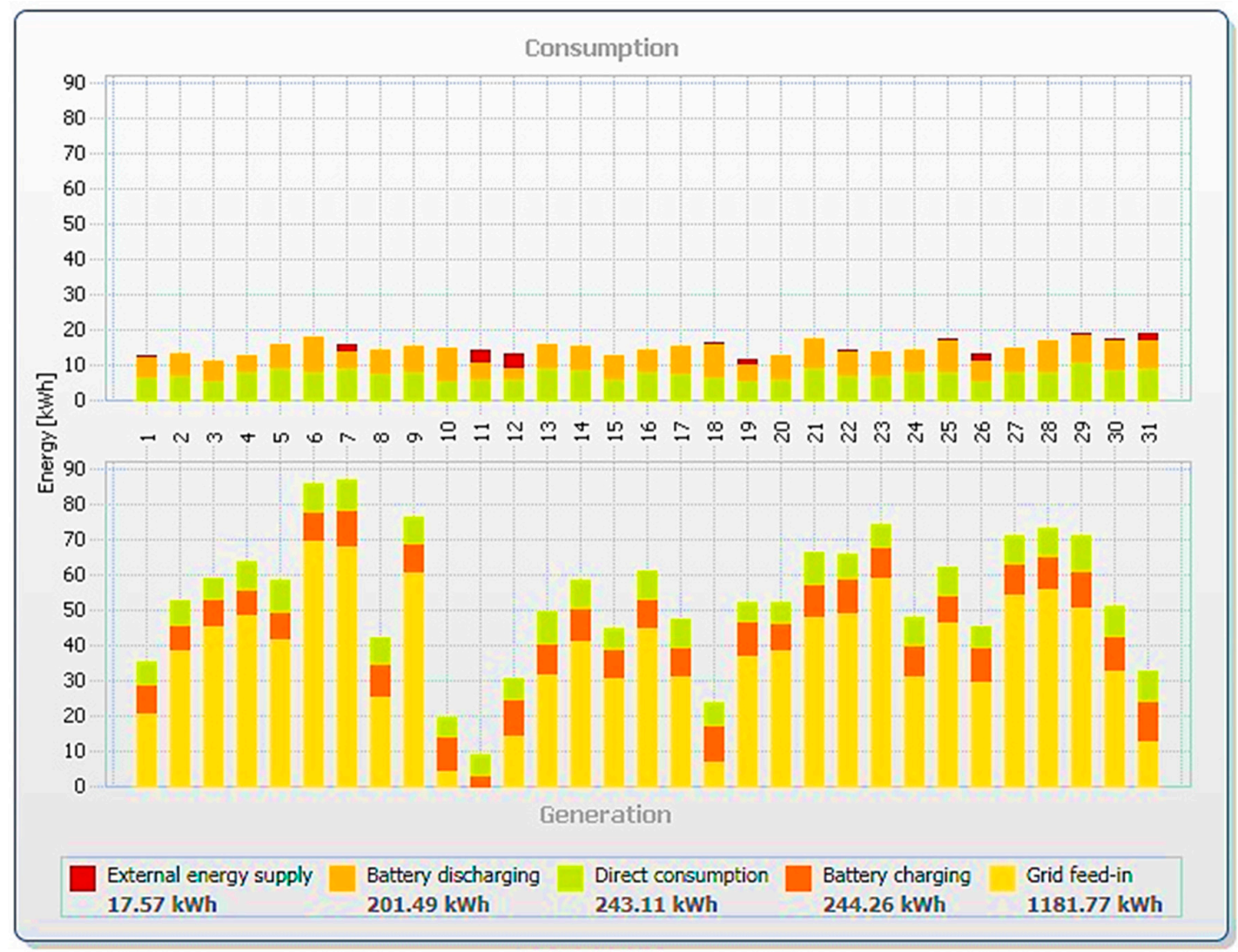

August 2017

Figure 6. Illustrating the main logic of calculations with energy balance data from an actual flexible storage PV system [84]. System informations: PV system power: 14.760 kW; Nominal battery capacity: 9800 Wh; Battery type: Lithium-Ion; Location: Kassel, Germany.

\subsection{Economic Background in the Analyzed Countries}

For economic calculations dynamic return indicators, such as the net present value (NPV), the profitability index (PI) and the discounted payback period (DPP), were used according to internationally applied methods [85]. The current interest rate needed for the calculation of the time value of the dynamic economic indicators was determined based on the 7 May 2018 status of long-term bond yields.

The authors assumed that the delivery price and the household electricity price of electric energy and the maintenance cost have an annual increase equal to the rate of average inflation (2014-2017). For the calculation of long-term income expectations, the yield data of 30-year government bonds were taken into account.

The annual cash flow is calculated as the sum of the household electricity costs saved (daytime and evening use) and the delivery price of the extra electric energy minus the maintenance costs. The time value is taken into account for the delivery price, the household electricity costs saved and the maintenance cost. Here, $100 \%$ own capital is calculated for the necessary investment for the systems based on the current market situation [86-93]. A positive measure is the Self-Generation Incentive Program (SGIP) in California in the USA, where homeowners who are customers of either Pacific Gas \& Electric (PG\&E), Southern California Edison (SCE), the Southern California Gas Company, or San Diego Gas \& Electric (SDG\&E) will be eligible for an incentive as high as $\$ 400 / \mathrm{kWh}$ battery size, when someone installs a home battery $[94,95]$. In the calculations, gross values were used because this calculation is valid only for households and not for businesses. Table 4 summarizes the bond yield interest rates, delivery price of electric energy and the electricity consumption of an average household in the analyzed 
countries. In Germany, the Federal Government is currently providing funding for the development of energy storage systems. About 200 million Euros have been awarded since 2012 for a total of around 250 projects. The projects benefitting from the funding initiative range from electrochemical technologies in households to MW storage systems. The funding program will run until 2018 [96].

Table 3. Bond yield interest rates, delivery price of electric energy and the electricity consumption of an average household in the analyzed countries [50,85,87-93,97].

\begin{tabular}{ccccc}
\hline & Germany & Italy & Spain & France \\
\hline $\begin{array}{c}\text { Average electricity consumption of } \\
\text { households / 2014/capita (kWh) }\end{array}$ & 1586 & 1074 & 1530 & 2197 \\
\hline $\begin{array}{c}\text { Average electricity consumption of } \\
\text { households / 2014/4 persons (kWh) }\end{array}$ & 6344 & 4296 & 6120 & 8788 \\
\hline Rate of average inflation (2014-2017) $(\%)$ & 0.92 & 0.36 & 0.28 & 0.44 \\
\hline Bond yield interest rate, 07 May 2018 (\%) & 1.23 & 2.93 & 2.42 & 1.66 \\
\hline $\begin{array}{c}\text { Typical delivery price for electric energy in the case } \\
\text { of a 5 kW system in 2017 (EURO cent/kWh) }\end{array}$ & 12.7 & 17.1 & 15.04 & 18.48 \\
\hline $\begin{array}{c}\text { Household electricity prices including all taxes and } \\
\text { levies in 2017 (EURO cent/kWh) }\end{array}$ & 30.5 & 21.4 & 23.0 & 16.9 \\
\hline
\end{tabular}

* The delivery price for electric energy may change from month to month.

\section{Economic Aspects of the Flexible Storage PV Systems}

The necessary replacement of the batteries and the inverters determines the maintenance costs, which are written in Table 4 . There are big differences between the maintenance costs: the Olivinetype- $\mathrm{LiFePO}_{4}$ systems have the minimum value, which is only a quarter of the maintenance costs of the Absorbent Glass Mat (AGM) systems. The reason is mainly the average cycle stability based on depth of discharge (DOD). In the case of daily use AGM batteries should be replaced approx. every two years, while the Olivine-type- $\mathrm{LiFePO}_{4}$ technology is capable of 30 years of operation.

Besides the electricity delivery price and the bond yield and the inflation rates it is the maintenance cost that has a big influence on the net present value of the investment.

Table 4. Calculated maintenance costs for different battery types in the studied countries.

\begin{tabular}{cccccccc}
\hline $\begin{array}{c}\text { Maintenance Costs } \\
\text { (Thousand EUR) }\end{array}$ & AGM & AHI & Li-ion & LiFePO $_{4}$ & Olivine-Type-LiFePO $_{4}$ & OPzS & OPzV \\
\hline Germany & 30.9 & 20.6 & 12.9 & 19.2 & 7.4 & 17.5 & 20.9 \\
Italy & 28.5 & 18.8 & 11.7 & 17.4 & 6.8 & 16.1 & 19.2 \\
Spain & 28.1 & 18.6 & 11.6 & 17.1 & 6.7 & 15.9 & 18.9 \\
France & 28.8 & 19.1 & 11.9 & 17.6 & 6.9 & 16.3 & 19.4 \\
\hline
\end{tabular}

Figure 7 shows us the investment indexes of a flexible storage PV system. The best economic environments to build flexible storage PV systems are in Germany and in Spain due to the high electricity prices. Italy and France have negative NPVs within a 30-year period, which means their discounted payback periods (DPP) are longer than 30 years. Own usage was calculated besides selling the electricity. All the studied countries except France have higher electricity prices for households than delivery prices from PV systems. The DPP was not indicated in the case of the $\mathrm{AGM}$ and $\mathrm{LiFePO}_{4}$ flexible PV storage systems in the Figure 7 because these payback periods were longer than 30 years.

In France, the household electricity price is lower than the delivery price of electric energy from PV systems. Consequently, a standard PV system produces more profit than a flexible storage one. In this case the best solution is to sell the electricity rather than use it for own consumption.

The difference between the household electricity price and the delivery price are more than twice in Germany, thus the country could be a good economic environment for flexible storage PV investments. The results show positive NPVs in Germany and in Spain for the following technologies: 
- $\quad$ Olivine-type-LiFePO

- Lithium-Ion;

- OPzS;

- $\mathrm{AHI} ;$

- $\mathrm{OPzV}$ (It has only positive NPV in Germany).

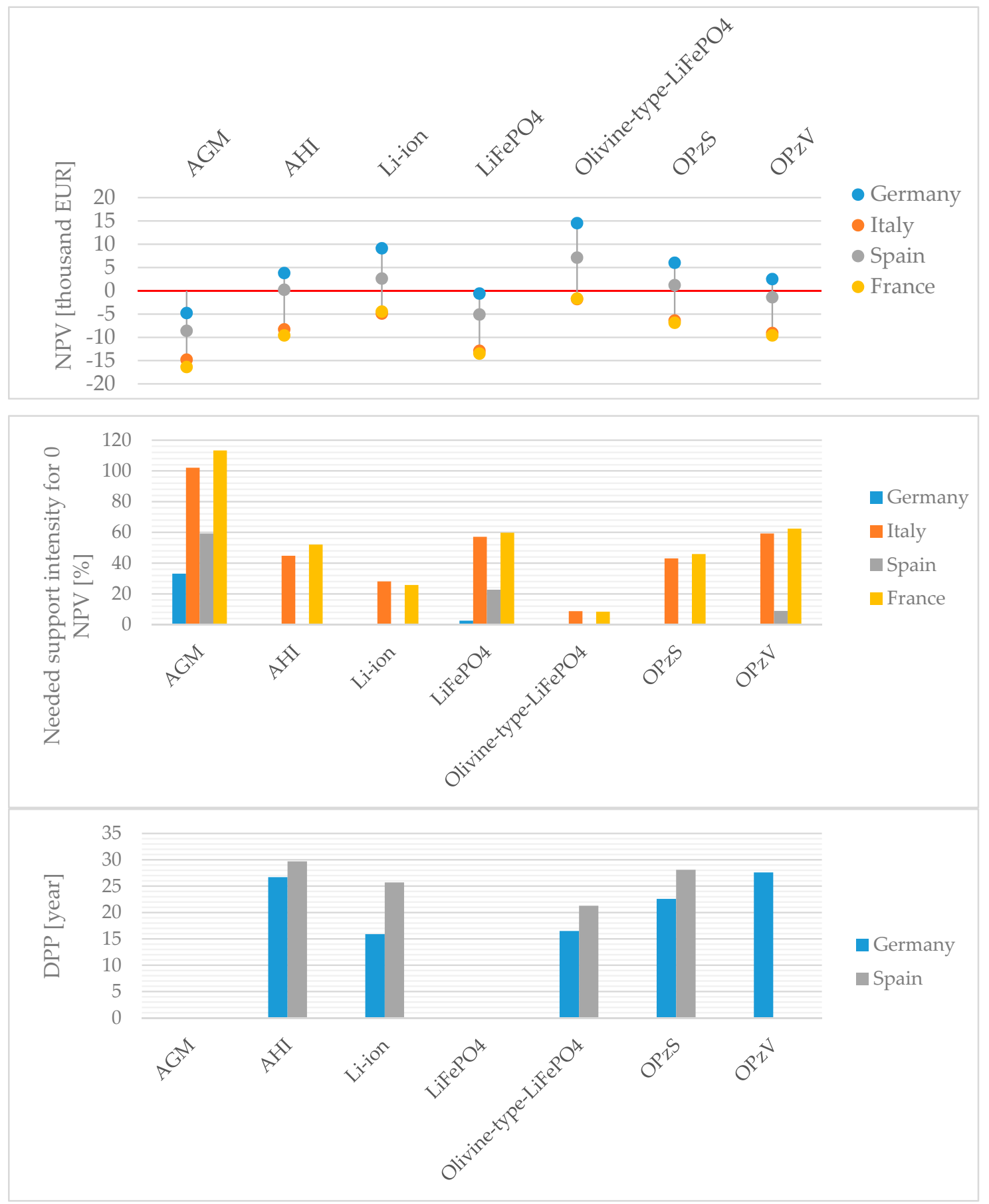

Figure 7. Net present values, needed support for 0 present value (NPV) in percentage of the total investment cost and discounted payback periods (DPP) by battery type in the studied countries within a 30-year period. 
The DPP of the Olivine-type- $\mathrm{LiFePO}_{4}$ and the Li-ion batteries are around 15 years. Li-ion and the Olivine-type- $\mathrm{LiFePO}_{4}$ batteries have the best NPVs, and these are the most cost-effective technologies among of the studied systems. Building a flexible storage system with these batteries can be profitable in Germany and in Spain within 30 years. OPzS and AHI also have positive NPVs in both countries, and the OPzV have a positive NPV in Germany. Only the AGM and the $\mathrm{LiFePO}_{4}$ batteries have negative NPVs in all studied countries. Figure 7 shows the results of the economic calculations. Besides the NPV, the support intensity needed for $0 \mathrm{NPV}$ in percentage of the total investment cost and the DPP are also calculated. For the spread of safe decentralized energy production and flexible storage PV systems in Europe it would be effective to implement a California-like "Self-Generation Incentive Program" support system. Using flexible storage PV systems in the future can be a goal of every country that does not want to lose "the race for green energy."

\section{Conclusions}

In this research project, seven different flexible storage PV investments were analyzed in Germany, France, Italy, and Spain because these countries have a prominent role concerning the spread of PV technology in Europe.

It was an important question whether it is possible in the European Union to achieve a payback of the costs of flexible storage photovoltaic system investments for residential customers considering the technology-specific storage aspects prevalent in 2018. As a result of the above investigations it was found that under the appropriate economic conditions it is possible to reach that goal in the European Union in 2018. Based on the research, two flexible storage technologies were chosen as the best: $\mathrm{Li}$-ion and the Olivine-type- $\mathrm{LiFePO}_{4}$. The $\mathrm{Li}$-ion has lower investment costs but also a lower NPV than the Olivine-type-LiFePO storage PV system with Olivine-type-LiFePO4 and Li-ion can be profitable in Germany and in Spain, and the discounted payback period of the investment was between 15-26 years in 2018. The other technologies (expect the AHI and OPzS, which also have positive NPVs) currently available in the studied markets cannot be competitive with the above mentioned two investments.

A flexible storage PV system costs the same in the four countries studied but the maintenance costs, the delivery price for electric energy, the bond yields, and the inflation and interest rates are different, and they have a significant influence on investments. Countries that do not want to lose the competition of using renewable energy sources in a "smart world" should allocate enough money for such supports.

A continuous development of flexible storage PV technologies is required in the future. In the short run, governmental support and uniform European modifications to the regulatory framework, especially concerning grid fees and tariffs, will be necessary to help to introduce these flexible storage PV systems to the market. In the future, the European Union should invest more in product development in the promising directions to become competitive in flexible energy storage technologies.

Author Contributions: H.Z. was mainly responsible for the technological aspects, conceived and designed the manuscript and supervised the economic aspects. G.P. investigated the economic aspects and carried out the main economic calculations. N.H.B. provided invaluable help with the calculations and created the graphs and tables for the paper. I.H. examined the new battery technologies (including 3D printing) and gave advice related to them. A.V. studied the international aspects related to the subject of the research and provided linguistic supervision and assistance.

Acknowledgments: The article was sponsored by the GINOP 2.3.2-15-2016-00022 grant.

Conflicts of Interest: The authors declare no conflict of interest.

\section{Abbreviations}

The following abbreviations are used in this manuscript: 


$\begin{array}{ll}\text { AGM } & \text { Absorbent Glass Mat } \\ \text { AHI } & \text { Aqueous Hybrid Ion } \\ \text { DOD } & \text { Depth of discharge } \\ \text { DPP } & \text { Discounted payback period } \\ \text { GHI } & \text { Global horizontal irradiation } \\ \text { LiFePO }_{4} & \text { Lithium-Iron-Phosphate } \\ \text { Li-ion } & \text { Lithium-Ion } \\ \text { m-Si modules } & \text { Monocrystalline modules } \\ \text { NPV } & \text { Net present value } \\ \text { NREL } & \text { National Renewable Energy Laboratory } \\ \text { Olivine-type-LiFePO } 4 & \text { Olivine-type-Lithium-Iron-Phosphate } \\ \text { OPzS } & \text { Vented lead-acid battery } \\ \text { OPzV } & \text { Sealed lead-acid battery } \\ \text { PG\&E } & \text { Pacific Gas \& Electric } \\ \text { PGIS } & \text { Photovoltaic Geographical Information System } \\ \text { PI } & \text { Profitability index } \\ \text { p-Si modules } & \text { Polycrystalline modules } \\ \text { PV } & \text { Photovoltaic } \\ \text { SCE } & \text { Southern California Edison } \\ \text { SDG\&E } & \text { San Diego Gas \& Electric } \\ \text { SGIP } & \text { Self-Generation Incentive Program }\end{array}$

\section{References}

1. Zafar, R.; Mahmood, A.; Razzaq, S.; Ali, W.; Naeem, U.; Shehzad, K. Prosumer based energy management and sharing in smart grid. Renew. Sustain. Energy Rev. 2018, 82, 1675-1684. [CrossRef]

2. Zame, K.K.; Brehm, C.A.; Nitica, A.T.; Richard, C.L.; Schweitzer, G.D., III. Smart grid and energy storage: Policy recommendations. Renew. Sustain. Energy Rev. 2018, 82, 1646-1654. [CrossRef]

3. Kordmahaleh, A.A.; Naghashzadegan, M.; Javaherdeh, K.; Khoshgoftar, M. Design of a 25 MWe Solar Thermal Power Plant in Iran with Using Parabolic Trough Collectors and a Two-Tank Molten Salt Storage System. Int. J. Photoenergy 2017, 2017, 1-11. [CrossRef]

4. Noman, A.M.; Addoweesh, K.E.; Alolah, A.I. Simulation and Practical Implementation of ANFIS-Based MPPT Method for PV Applications Using Isolated Ćuk Converter. Int. J. Photoenergy 2017, 2017, 1-15. [CrossRef]

5. Daliento, S.; Chouder, A.; Guerriero, P.; Pavan, A.M.; Mellit, A.; Moeini, R.; Tricoli, P. Monitoring, Diagnosis, and Power Forecasting for Photovoltaic Fields: A Review. Int. J. Photoenergy 2017, 2017, 1-13. [CrossRef]

6. Cucchiella, F.; D'Adamo, I. A Multicriteria Analysis of Photovoltaic Systems: Energetic, Environmental, and Economic Assessments. Int. J. Photoenergy 2015, 2015, 1-8. [CrossRef]

7. D'Adamo, I.; Miliacca, M.; Rosa, P. Economic Feasibility for Recycling of Waste Crystalline Silicon Photovoltaic Modules. Int. J. Photoenergy 2017, 2017, 1-6. [CrossRef]

8. Fraunhofer Institute for Solar Energy Systems (ISE). Annual Report 2016/2017; Fraunhofer Institute for Solar Energy Systems ISE: Freiburg, Germany, 2017; pp. 1-88.

9. Fraunhofer Institute for Solar Energy Systems (ISE). Photovoltaics Report; Fraunhofer Institute for Solar Energy Systems ISE: Freiburg, Germany, 2017; pp. 1-45.

10. Panagea, I.S.; Tsanis, I.K.; Koutroulis, A.G.; Grillakis, M.G. Climate Change Impact on Photovoltaic Energy Output: The Case of Greece. Adv. Meteorol. 2014, 2014,1-11. [CrossRef]

11. REN21. Renewable Energy Policy Network for the 21st Century Renewables 2017; Global Status Report-REN21; REN21: Paris, France, 2017; pp. 1-302.

12. International Renewable Energy Agency (IRENA). Solar PV in Africa: Costs and Markets; IRENA: Abu Dhabi, UAE, 2016.

13. China National Energy Board. 2016 Photovoltaic Power Generation Statistics. Available online: http: / / www.nea.gov.cn/2017-02/04/c_136030860.htm (accessed on 4 February 2018).

14. Eurostat. Infrastructure-Electricity-Annual Data. Available online: http://ec.europa.eu/eurostat/en/ web/products-datasets/-/NRG_113A (accessed on 4 February 2018). 
15. European Commission. EU Reference Scenario 2016; EC: Brussels, Belgium, 2016.

16. National Renewable Energy Laboratory (NREL). Exploration of High-Penetration Renewable Electricity Futures; NREL: Golden, CO, USA, 2012; Volume 1.

17. National Renewable Energy Laboratory (NREL). Renewable Electricity Generation and Storage Technologies; NREL: Golden, CO, USA, 2012.

18. Sandia National Laboratories DOE Global Energy Storage Database. Available online: https://www. energystorageexchange.org/projects/data_visualization (accessed on 2 May 2018).

19. Bertsch, J.; Growitsch, C.; Lorenczik, S.; Nagl, S. Flexibility in Europe's power sector-An additional requirement or an automatic complement? Energy Econ. 2016, 53, 118-131. [CrossRef]

20. Hesse, H.; Schimpe, M.; Kucevic, D.; Jossen, A. Lithium-Ion Battery Storage for the Grid-A Review of Stationary Battery Storage System Design Tailored for Applications in Modern Power Grids. Energies 2017, 10, 2107. [CrossRef]

21. Schimpe, M.; Piesch, C.; Hesse, H.; Paß, J.; Ritter, S.; Jossen, A. Power Flow Distribution Strategy for Improved Power Electronics Energy Efficiency in Battery Storage Systems: Development and Implementation in a Utility-Scale System. Energies 2018, 11, 533. [CrossRef]

22. Aneke, M.; Wang, M. Energy storage technologies and real life applications-A state of the art review. Appl. Energy 2016, 179, 350-377. [CrossRef]

23. Han, X.; Liao, S.; Ai, X.; Yao, W.; Wen, J. Determining the Minimal Power Capacity of Energy Storage to Accommodate Renewable Generation. Energies 2017, 10, 468. [CrossRef]

24. Blanco, H.; Faaij, A. A review at the role of storage in energy systems with a focus on Power to Gas and long-term storage. Renew. Sustain. Energy Rev. 2018, 81, 1049-1086. [CrossRef]

25. Strbac, G.; Aunedi, M.; Pudjianto, D.; Djapic, P.; Teng, F.; Sturt, A.; Jackravut, D.; Sansom, R.; Yufit, V.; Brandon, N. Strategic Assessment of the Role and Value of Energy Storage Systems in the UK Low Carbon Energy Future; Imperial College London: London, UK, 2012.

26. Denholm, P.; Ela, E.; Kirby, B.; Milligan, M. Role of Energy Storage with Renewable Electricity Generation; National Renewable Energy Laboratory (NREL): Golden, CO, USA, 2010.

27. International Renewable Energy Agency. Electricity Storage and Renewables: Costs and Markets to 2030; IREA: Abu Dhabi, UAE, 2017.

28. Kondziella, H.; Bruckner, T. Flexibility requirements of renewable energy based electricity systemsA review of research results and methodologies. Renew. Sustain. Energy Rev. 2016, 53, 10-22. [CrossRef]

29. Beaudin, M.; Zareipour, H.; Schellenberglabe, A.; Rosehart, W. Energy storage for mitigating the variability of renewable electricity sources: An updated review. Energy Sustain. Dev. 2010, 14, 302-314. [CrossRef]

30. Deane, J.P.; Gallachóir, B.P.Ó.; McKeogh, E.J. Techno-economic review of existing and new pumped hydro energy storage plant. Renew. Sustain. Energy Rev. 2010, 14, 1293-1302. [CrossRef]

31. Chen, H.; Cong, T.N.; Yang, W.; Tan, C.; Li, Y.; Ding, Y. Progress in electrical energy storage system: A critical review. Prog. Nat. Sci. 2009, 19, 291-312. [CrossRef]

32. International Hydropower Association. 2017 Key Trends in Hydropower; International Hydropower Association: London, UK, 2017.

33. International Renewable Energy Agency (IRENA). Renewable Energy Capacity Statistics 2017; IRENA: Abu Dhabi, UAE, 2017.

34. Sandia National Laboratories. DOE Global Energy Storage Database, Office of Electricity Delivery \& Energy Reliability. Available online: http:/ / www.energystorageexchange.org/projects (accessed on 2 May 2018).

35. Luo, X.; Wang, J.; Dooner, M.; Clarke, J. Overview of current development in electrical energy storage technologies and the application potential in power system operation. Appl. Energy 2015. [CrossRef]

36. May, G.J.; Davidson, A.; Monahov, B. Lead batteries for utility energy storage: A review. J. Energy Storage 2018, 15, 145-157. [CrossRef]

37. Ugarte, S.; Larkin, J.; Ree, B.; Van der Swinkels, V.; Voogt, M.; Friedrichsen, N.; Michaelis, J.; Thielmann, A.; Wietschel, W.; Wietschel, R. Energy Storage: Which Market Designs and Regulatory Incentives Are Needed? European Parliament Committee on Industry, Research and Energy: Brussels, Belgium, 2015.

38. ENTSO-E Maps \& Data, TYNDP 2016 Storage Projects. Available online: http://tyndp.entsoe.eu/mapsdata/ (accessed on 27 May 2018). 
39. Haller, M.; Ludig, S.; Bauer, N. Decarbonization scenarios for the EU and MENA power system: Considering spatial distribution and short term dynamics of renewable generation. Energy Policy 2012, 47, 282-290. [CrossRef]

40. Bloomberg New Energy Finance. Beyond the Tipping Point_Flexibility Gaps in Future High-Renewable Energy Systems in the U.K., Germany and Nordics; Bloomberg New Energy Finance: New York, NY, USA, 2018.

41. SMA Solar Technology AG. Sunny Island 3.0M/4.4M I SMA Solar. Available online: https://www.sma.de/ en/products/battery-inverters/sunny-island-30m-44m.html (accessed on 4 February 2018).

42. Subramani, G.; Ramachandaramurthy, V.K.; Padmanaban, S.; Mihet-Popa, L.; Blaabjerg, F.; Guerrero, J.M. Grid-tied photovoltaic and battery storage systems with Malaysian electricity tariff-A review on maximum demand shaving. Energies 2017, 10, 1884. [CrossRef]

43. European Commission. JRC Photovoltaic Geographical Information System (PVGIS). Available online: http:/ / re.jrc.ec.europa.eu/pvg_tools/en/tools.html\#PVP (accessed on 2 February 2018).

44. Olaszi, D.B.; Ladanyi, J. PV system auto-sizing with battery energy storage based on gps coordinates. Pollack Periodica 2017, 12, 29-41. [CrossRef]

45. Solargis.com. Solar Resource Maps and GIS Data for 200+ Countries I Solargis. Available online: https: / / solargis.com/products/maps-and-gis-data/download/ (accessed on 4 February 2018).

46. SMA Solar Technology AG. Sunny Portal, Publicly Available PV System, Germany-HE7a. Available online: https: / / www.sunnyportal.com/Templates /PublicPageOverview.aspx?page=ca457d7d-1705-4b4b-871ee397664aebc3\&plant=2e1e792f-f037-45dc-86dd-f16087cb936a\&splang=en-US (accessed on 4 February 2018).

47. SMA Solar Technology AG. Sunny Portal, Publicly Available PV System, Spain—Laura FV. Available online: https: / / www.sunnyportal.com/Templates/PublicPageOverview.aspx?page=b08ef5d2-7565-4289-babaffaaab52dbb2\&plant=4aa0ea28-9c08-409c-bbcf-570fd91103e7\&splang=en-US (accessed on 4 February 2018).

48. SMA Solar Technology AG. Sunny Portal, Publicly Available PV System, Italy-Solarme 60 Di Salvo. Available online: https:/ / www.sunnyportal.com/Templates / PublicPageOverview.aspx?page=91adf499a536-4d53-8007-567cecfd6a9d\&plant=bf2a8a75-cc5d-48c2-aa9d-50fe0402cf0d\&splang=en-US (accessed on 4 February 2018).

49. SMA Solar Technology AG. Sunny Portal, Publicly Available PV System, France-cregut@limayrac. Available online: https:/ / www.sunnyportal.com/Templates / PublicPageOverview.aspx?page=6938d7af3227-4dc7-a6e8-539793d952f9\&plant=2ff1cb6b-13be-4876-b3e4-8554c2bee81e\&splang=en-US (accessed on 4 February 2018).

50. European Commission. Legal Sources on Renewable, Germany, Spain, Italy, France. Available online: http:/ / www.res-legal.eu/search-by-country/ (accessed on 13 February 2018).

51. Jordan, D.C.; Kurtz, S.R. Photovoltaic Degradation Rates-an Analytical Review. Prog. Photovolt. Res. Appl. 2013, 21, 12-29. [CrossRef]

52. Kim, H.; Park, K.-Y.; Hong, J.; Kang, K. All-graphene-battery: Bridging the gap between supercapacitors and lithium ion batteries. Sci. Rep. 2015, 4, 5278. [CrossRef] [PubMed]

53. Kato, Y.; Hori, S.; Saito, T.; Suzuki, K.; Hirayama, M.; Mitsui, A.; Yonemura, M.; Iba, H.; Kanno, R. High-power all-solid-state batteries using sulfide superionic conductors. Nat. Energy 2016, 1, 16030. [CrossRef]

54. Edwards, L. Nanowire Battery Can Extend Your Phone Battery Life by Hundreds of Thousands of Times-Pocket-Lint. Available online: https://www.pocket-lint.com/gadgets/news/137387-nanowirebattery-can-extend-your-phone-battery-life-by-hundreds-of-thousands-of-times (accessed on 7 May 2018).

55. Lim, C.; Yan, B.; Yin, L.; Zhu, L. Geometric Characteristics of Three Dimensional Reconstructed Anode Electrodes of Lithium Ion Batteries. Energies 2014, 7, 2558-2572. [CrossRef]

56. Sun, K.; Wei, T.-S.; Ahn, B.Y.; Seo, J.Y.; Dillon, S.J.; Lewis, J.A. 3D Printing of Interdigitated Li-Ion Microbattery Architectures. Adv. Mater. 2013, 25, 4539-4543. [CrossRef] [PubMed]

57. TST Arge Solarstrom. Photovoltaic Storage Systems. Available online: https:/ www.photovoltaik-shop. com/storage-systems.html (accessed on 13 February 2018).

58. Figgener, J.; Haberschusz, D.; Kairies, K.-P.; Wessels, O.; Tepe, B.; Ebbert, M.; Herzog, R.; Sauer, D.U. Wissenschaftliches Mess-und Evaluierungsprogramm Solarstromspeicher 2.0; Hg. v. Institut für Stromrichtertechnik und Elektrische Antriebe der RWTH Aachen: Aachen, Germany, 2016.

59. TST Arge Solarstrom. Complete PV Systems, Prices. Available online: https:/ /www.photovoltaik-shop. com/pv-komplettanlagen.html (accessed on 4 February 2018). 
60. Euronorm Group Builder Kft. PV System Installation Prices. Available online: http://ceginformacio. creditreform.hu/cr9317990317 (accessed on 4 February 2018).

61. Bács-Zöldenergia Kft. Prices and System Installation Prices. Available online: http://bze.hu/napelem-arak (accessed on 4 February 2018).

62. SOLARWATT GmbH. SOLARWATT MyReserve 500. Available online: https://www.solarwatt.de/ stromspeicher/myreserve-500 (accessed on 4 February 2018).

63. EFT-Systems GmbH. B-Box HV. Available online: http:/ / www.eft-systems.de/de/ (accessed on 4 February 2018).

64. Fronius International GmbH. Fronius Energy Package. Available online: http://www.fronius.com/ en/photovoltaics / products/all-products/solutions / fronius-storage-solution/fronius-energy-package / fronius-energy-package (accessed on 4 February 2018).

65. TST Arge Solarstrom. Fronius Battery 4.5, Prices. Available online: https:/ /www.photovoltaik-shop.com/ fronius-battery-4-5.html (accessed on 4 February 2018).

66. KOSTAL Solar Electric GmbH. PIKO Battery Li and PIKO Battery Pb. Available online: https://ch.krannichsolar.com/fileadmin/content/data_sheets/storage_systems/kostal_DB_PIKO_BA_System-Pb-Li_DE.pdf (accessed on 4 February 2018).

67. Sony Europe Ltd. Sony IJ1001MNB-SY6. Available online: https://www.photovoltaik-shop.com/ downloads/dl/file/id/1048/de_sony_erweiterungsset_datenblatt_pdf.pdf (accessed on 4 February 2018).

68. TST Arge Solarstrom. Sony IJ1001MNB-SY6, Prices. Available online: https://www.photovoltaik-shop. com/erweiterungsset-sony-stromspeichereinheit-ij1001mnb-sy6-inkl-cu-verbinder-und-datenkabel.html (accessed on 4 February 2018).

69. TAB Tovarna Akumulatorskih Baterij d. d. OPzS Batteries Technical Data. Available online: http://www. tab.si/pdf/katalogi/TAB_stationary_tech/TAB_Stationary_tech.pdf (accessed on 4 February 2018).

70. HOPPECKE Batterien GmBh \& Co. KG. OPzS bloc Solar.Power. Available online: https:/ / www.photovoltaikshop.com/downloads/dl/file/id/91/akku_hoppecke_opzs_bloc_solar_power_12v_200_datenblatt_pdf.pdf (accessed on 4 February 2018).

71. TST Arge Solarstrom. Akku Hoppecke 12V 3 OPzS Bloc Solar.Power 200, Prices. Available online: https: / / www.photovoltaik-shop.com/akku-hoppecke-12v-3-opzs-bloc-solar-power-200.html (accessed on 4 February 2018).

72. Hoppecke Batterien GmBh \& Co. KG. Solar.bloc. Valve Regulated Lead-Acid Batteryes for Cyclic Applications. Available online: http://www.off-grid-europe.com/downloads/dl/file/id/136/solar_bloc_datasheet.pdf (accessed on 4 February 2018).

73. EnerSys Europe (EMEA). PowerSafe OPzV Operation Guide for Solar Applications. Available online: http:/ / webcache.googleusercontent.com/search?q=cache:fOsf89cvafYJ:www.enersys.com/WorkArea/ DownloadAsset.aspx\%3Fid\%3D25769806543+\&cd=1\&hl=hu\&ct=clnk\&gl=hu (accessed on 4 February 2018).

74. Wattuneed. Battery Hoppecke Opzv Solar.Power, Prices. Available online: https://www.wattuneed.com/ en / premium-battery /767-battery-hoppecke-opzv-solarpower-0712971127425.html\#/hoppecke_opzvopzv_12_solar_power_1500 (accessed on 4 February 2018).

75. Hoppecke Batterien GmbH \& Co. KG. Installation, Commissioning and Operating Instructions, for Vented Stationary Lead-Acid Batteries. Available online: https:/ /www.hoppecke.com/fileadmin/Redakteur/HoppeckeMain/Products/Downloads/Montagehandbuch_geschl_EN_final.pdf (accessed on 4 February 2018).

76. SMA Solar Technology AG. Sunny Boy 3000TL/3600TL/4000TL/5000TL with Reactive Power Control. Available online: https://www.sma-uk.com/products/solarinverters/sunny-boy-3000tl-3600tl-4000tl5000tl-with-reactive-power-control.html (accessed on 4 February 2018).

77. TST Arge Solarstrom. Akku 12 Volt Hoppecke Solar.Bloc 150, Prices. Available online: https://www. photovoltaik-shop.com/hoppecke-solar-bloc-12v-150.html (accessed on 4 February 2018).

78. Victron Energy. Blue Power. Gel and AGM Batteries. Available online: https://www.victronenergy.com/ upload/documents / Datasheet-GEL-and-AGM-Batteries-EN.pdf (accessed on 4 February 2018).

79. Aquion Energy, I.300 S-S080 Battery Stack. Available online: https://cdn2.hubspot.net/hubfs/147472/ 01_Product_Documentation/Aquion_Energy_S30-0080_Product_Specification_Sheet.pdf (accessed on 4 February 2018).

80. eBay Inc. Saltwater Batteries 100\% Discharge-Aquion Battery Stacks—24V, Prices. Available online: https:/ / www.ebay.com/itm/SALTWATER-Batteries-100-Discharge-Aquion-Battery-Stacks-24V/162251761532? hash=item25c6f5677c:g:vEkAAOSw4CFY2ujP (accessed on 4 February 2018). 
81. AXITEC Energy GmbH \& Co. KG. AXIstorage Li 7S; AXITEC Energy GmbH \& Co. KG: Böblingen, Germany, 2018.

82. TST Arge Solarstrom. AxIstorage Li 7S FOR SMA, Prices. Available online: https:/ /www.photovoltaikshop.com/batterie-axistorage-li-7s-for-sma.html (accessed on 4 February 2018).

83. Samsung SDI Europe GmbH. Energy Storage System for Home. Available online: https:/ /www.photovoltaikshop.com/downloads/dl/file/id/779/samsung_all_in_one_8_0_de_pdf.pdf (accessed on 4 February 2018).

84. SMA Solar Technology AG. Energy Balance—SMA Integrated Storage System—Sunny Portal. Available online: https:/ / www.sunnyportal.com/FixedPages/HoManEnergyRedesign.aspx (accessed on 26 May 2018).

85. Brealey, R.; Myers, S.; Allen, F. Principles of Corporate Finance; McGraw-Hill/Irwin: New York, NY, USA, 2003.

86. Zsiborács, H.; Pályi, B.; Pintér, G.; Popp, J.; Balogh, P.; Gabnai, Z.; Pető, K.; Farkas, I.; Baranyai, N.H.; Bai, A. Technical-economic study of cooled crystalline solar modules. Sol. Energy 2016, 140, 227-235. [CrossRef]

87. Enerdata, W.E.C. Energy Efficiency Indicators/Europe/Germany, Italy, Spain, France. Available online: https:/ / wec-indicators.enerdata.net/world.php (accessed on 4 February 2018).

88. Inflation.eu. Historic Inflation-CPI Inflation Year Pages, Germany, Italy, France, Spain. Available online: http:/ / www.inflation.eu/inflation-rates/historic-cpi-inflation.aspx (accessed on 4 February 2018).

89. Investing.com. European Government Bonds Yields, 30Y. Available online: https:/ / www.investing.com/ratesbonds / european-government-bonds?maturity_from=10\&maturity_to=310 (accessed on 4 February 2018).

90. PV Financing. Developement Limited by Regulation-Selfconsumption in Spain; PV Financing: Berlin, Germany, 2016; pp. 1-15.

91. European Commission. Res Regal. Legal Sources on Renewable Energy, Feed-in Tariff (EEG Feed-In Tariff), Germany. Available online: http:/ / www.res-legal.eu/search-by-country/germany/single/s/res-e/ t/promotion/aid/feed-in-tariff-eeg-feed-in-tariff/lastp/135/ (accessed on 4 February 2018).

92. Commission de Régulation de L'énergie. Consulter le Tableau des Tarifs, des Primes et des Coefficients à Partir de L'entrée en Vigueur de L'arrêté du 9 mai 2017 Portant sur les Installations Photovoltaïques Situées en Métropole, mis à jour en Octobre 2017. Available online: http:/ / www.cre.fr/operateurs / producteurs / obligations-d-achat (accessed on 4 February 2018).

93. PV Magazine. Feed-In Tariffs (FITs) in Europe, Italy. Available online: https:/ /www.pv-magazine.com/ features/archive/solar-incentives-and-fits / feed-in-tariffs-in-europe/\#italy (accessed on 4 February 2018).

94. Energysage. California Home Battery Rebate: Self-Generation Incentive Program (SGIP) Explained. Available online: https://news.energysage.com/california-energy-storage-incentives-sgip-explained/ (accessed on 4 February 2018).

95. Self-Generation Incentive Program Handbook. Provides Financial Incentives for Installing Clean, Efficient, On-Site Distributed Generation; Self-Generation Incentive Program: San Diego, CA, USA, 2017.

96. Federal Ministry of Economics and Technology. Funding Programmes for Energy Storage. Available online: https:/ / www.bmwi.de/Redaktion/EN/Artikel/Energy/foerderinitiative-energiespeicher.html (accessed on 27 May 2018).

97. European Commission Eurostat. Energy Prices in 2017-Household Energy Prices in the EU Down Compared with 2016; European Commission Eurostat: Luxemburg, 2017.

(C) 2018 by the authors. Licensee MDPI, Basel, Switzerland. This article is an open access article distributed under the terms and conditions of the Creative Commons Attribution (CC BY) license (http:/ / creativecommons.org/licenses/by/4.0/). 